\title{
ROLE OF THE EU, THE USA AND BRICS COUNTRIES IN GLOBAL TRADE IN GOODS AND SERVICES AND SELECTED DETERMINANTS
}

\author{
Dawid Jabkowski ${ }^{1}, \mathrm{MSc}$; Norbert Szalaty ${ }^{2}, \mathrm{MSc}$; Weronika Wyduba ${ }^{3}, \mathrm{MSc}$
}

Faculty of Economics and Social Sciences, Poznań University of Life Sciences

\begin{abstract}
The aim of this paper is to present changes in the role of EU countries, the USA and BRICS countries in international trade of goods and services and selected macroeconomic determinants of trade exchange in the analysed countries in the years 1960-2015 together with the projection of potential development of the situation until 2070. Investigated macroeconomic trade conditions included population size, GDP, GDP per capita and the inflation rate. Naive forecasting methods were used to estimate selected characteristics, as well as export and import volumes, considering their development trends. The analyses showed that currently, the largest global trade centres, i.e. the EU and the USA, are losing their share in global GDP. Their share in global exports and imports is decreasing to the advantage of BRICS countries. The simulation up to 2070 showed that the trends observed in previous years may be increasing, while the position of the EU and the USA in world trade may be weakening.
\end{abstract}

Keywords: international trade, exports, imports, population size, GDP, inflation rate, the EU, the USA, BRICS countries

JEL codes: F15, F17, F50

\section{INTRODUCTION}

The BRICS group is an association composed of Brazil, Russia, India, China and South Africa. O'Neill, the author of the BRICS acronym, stated that by 2050 BRICS countries will become global powers (O'Neill, 2001; Gosh, 2013). This means that these countries will compete and constitute a counterbalance to the current major players in the global economy, i.e. EU countries and the USA. Such trends have been observed since the mid-1990s. The growing political significance and economic potential of BRICS countries was discussed e.g. in The BRICS Report (2012), as well as by Nassif, Feijo and Araújo (2016) or Siddiqui (2016).

In 1995, the total share of the EU and the USA in the global exports of goods and services was approx. 51.5\% (40 and 11.5\%, respectively; Czarny and Folfas, 2015), while in 2015 it decreased to $44.3 \%$ (33.7 and 10.6\%, respectively). As it was reported by Czarny and Folfas (2015), the share of BRICS countries in global exports in the same period increased by $10 \mathrm{pp}$ (from 6 to 16\%). In absolute terms, the EU and the USA, in a period of 20 years (1995-2015), increased the value of their exports 3-fold, while for BRICS countries it was 11-fold, which means that

${ }^{1}$ Corresponding author: Wojska Polskiego 28, Poznań, Poland, dawid.jabkowski@up.poznan.pl, +48 723858996

${ }^{2}$ Corresponding author: Wojska Polskiego 28, Poznań, Poland, norbert.szalaty@up.poznan.pl, +4861 8466378

${ }^{3}$ Corresponding author: Wojska Polskiego 28, Poznań, Poland, weronika.wyduba@up.poznan.pl, +4861 8466378 
world exports are changing their location (Pawlas, 2015). Similarities of a comparable direction may also be observed for GDP. In 1995, the EU and the USA participated in the generation of GDP in $58 \%$ (30 and 28\%, respectively; Czarny and Folfas, 2015), while 20 years later the joint share of these countries in global GDP decreased to 48\% (22 and 24\%, respectively). In the same period BRICS countries increased their share in global GDP by 14 p.p. (from $8 \%$ in 1995 to $22 \%$ in 2015 ). It clearly results from the above that the balance of powers on the international market is changing. The Transatlantic Trade and Investment Partnership (TTIP) between the USA and the EU, which before the change of the American policy introduced by Trump's administration had been treated as a remedy to strengthen the cross-Atlantic bridge, may be considered an attempt to reinforce the weakening position of EU and US economies (Czarny and Folfas, 2015; Pawlak, 2017). In this context we may ask questions concerning factors, which have caused these current changes and may stimulate further changes in the international position of the countries under study. Thus, the aim of this paper is to present changes in the role of EU countries, the USA and BRICS countries in the international trade of goods and services and selected macroeconomic determinants of trade exchange between the investigated countries in the years 1960-2015 along with the projection of the potential development of the situation in this respect by the year 2070 .

\section{THEORETICAL BACKGROUND}

The development of trade was initiated by several factors, which later led to international trade expansion. Literature sources on the subject present various divisions of these factors. Porter divided them into two groups: micro- and macroeconomic, thus creating the so-called Porter's National Diamond (Porter, 1990; Bieńkowski, 2008). In turn, Rymarczyk (2006) presented an approach, in which he distinguished structural, technological, institutional and cyclical factors. The first category comprises differences in natural resources, mineral deposits, labour and capital resources (Budnikowski, 2003). The development of trade is also considerably affected by technological factors such as the Digital Revolution or industrial revolutions, which generated strong stimulants for economic growth (Budnikowski, 2003; Rymarczyk, 2006). A significant element in this group is connected with scientific and technological cooperation, the aim of which is to provide links between science and economy, e.g. R\&D. The importance of technological progress and innovation in shaping market shares was discussed by Schumpeter (1936) and Fagerberg (1987, 1996). Institutional factors include, among other things, the political system, the economic policy of a given country or international agreements (treaties, contracts) (Pelkmans, 2001; Rymarczyk, 2006). A solid foundation for the development of trade is also provided by cyclical factors (Budnikowski, 2003; Rymarczyk, 2006). Internal cyclical factors are connected with specific characteristics and conditions of individual economies, differentiating the predispositions of countries towards specific directions of international specialisation, while external factors are a result of development of international division of labour, resulting from structural transformations in the economy as a whole (Rymarczyk, 2006). Another approach to factors affecting the trade policy was given by Misala (2005), who distinguished long- and shortterm factors. In turn, Bożyk (2008), when referring to the conditions for the development of trade exchange, focused on the differences in natural conditions, in the level of industrialisation as well as technological standard. This paper will discuss selected quantitative structural and cyclical factors, determining the development of exports and imports (selected factors are widely taken into account in the analyses of trade development in developing countries, including BRICS, see e.g. Gururaj, Satishkumar and Aravinda Kumar (2016), whereby it is necessary to underline that the value of GDP and the share in global GDP are modified e.g. by technological factors, whereas the participation in global trade depends, to a considerable extent, on institutional factors.

\section{MATERIALS AND METHODS}

The analyses were based on literature on the subject and secondary data of the World Bank. The descriptive analysis and the deduction method were applied 
in this study. Naive forecasting methods were used to estimate the population size, GDP, export and import volumes for the year 2070, considering their development trends (Cieślak, 2005). The selected method assumes that the forecasted variable increases/decreases from period to period by a certain constant value $d$ :

$$
\hat{\mathrm{y}}_{T}=y_{T-1}+d
$$

The value $d$ was determined based on mean annual increments of the variable in the collected statistical material taking into consideration fluctuations of the variables in the years 2000-2015 (Błaszczuk, 2006).

$$
d=\frac{\sum_{i=1}^{T-2}\left(y_{i+1}-y_{i}\right)}{T-2}
$$

The projection adopted a simplifying assumption that in future periods the development trend observed in the years 2000-2015 will continue. This approach is used, among others, in FAOSTAT projections and is sufficient to capture the direction of changes in the forecasted variables and their potential impact on the share in global trade.

\section{RESULTS AND DISCUSSION}

In 1960, the largest volume of goods was exported from the European Union. These exports, amounting to USD 66 billion, accounted for over $42 \%$ of world exports (Table 1). Despite the 100 -fold increase in the value of exports from the EU by the year 2015, the share of this group of countries in global exports decreased to $34 \%$. A similar situation was observed in the USA where, in 1960, the value of exports at USD 27 billion was equivalent to $17 \%$ of global exports, while in 2015 , after an almost 90 -fold increase to USD 2.3 trillion, accounted for as little as $10 \%$ of world exports. At the same time, in BRICS countries, the value of exports not only increased, but also the share of this group of countries in world exports increased from 5\% in 1960 to $17 \%$ in 2015 . A very high dynamic for the increase in trade turnover in BRICS countries was observed in the years 2000-2012, when exports increased 6-fold and imports increased 8-fold, respectively (Pawlas, 2015). The conducted projection shows that, by 2070 , the share of BRICS countries in world exports may increase to $19 \%$, whereas that of EU countries and the USA may decrease to approx. $32.5 \%$ and a little below $10 \%$, respectively (Table 1 ).

Table 1. Values of trade in goods and services and shares of the EU, the USA and BRICS countries in world exports and imports in the years 1960-2070

\begin{tabular}{|l|c|c|c|c|c|c|c|c|c|c|c|c|}
\hline \multirow{2}{*}{ Item } & \multicolumn{3}{|c}{$\begin{array}{c}\text { Exports } \\
\text { (USD billion) }\end{array}$} & \multicolumn{3}{c|}{$\begin{array}{c}\text { Share in global exports } \\
(\%)\end{array}$} & \multicolumn{3}{c|}{$\begin{array}{c}\text { Imports } \\
\text { (USD billion) }\end{array}$} & \multicolumn{3}{c|}{$\begin{array}{c}\text { Share in global imports } \\
(\%)\end{array}$} \\
\cline { 2 - 17 } & 1960 & 2015 & 2070 & 1960 & 2015 & 2070 & 1960 & 2015 & 2070 & 1960 & 2015 & 2070 \\
\hline World & 157 & 21310 & 63828 & 100 & 100 & 100 & 159 & 20835 & 62633 & 100 & 100 & 100 \\
\hline EU & 66 & 7172 & 20808 & 42.1 & 33.7 & 32.6 & 68 & 6608 & 18673 & 42.7 & 31.7 & 29.8 \\
\hline USA & 27 & 2264 & 6346 & 17.2 & 10.6 & 9.9 & 23 & 2786 & 7720 & 14.3 & 13.4 & 12.3 \\
\hline BRICS, including: & 8 & 3573 & 12315 & 4.8 & 16.8 & 19.3 & 8 & 3151 & 11274 & 5.1 & 15.1 & 18.0 \\
\hline Brazil & 1 & 232 & 755 & 0.7 & 1.1 & 1.2 & 1 & 254 & 692 & 0.7 & 1.2 & 1.1 \\
\hline Russia & 0 & 392 & 1109 & 0.0 & 1.8 & 1.7 & 0 & 281 & 939 & 0.0 & 1.4 & 1.5 \\
\hline India & 2 & 421 & 1646 & 1.0 & 2.0 & 2.6 & 3 & 470 & 1756 & 1.6 & 2.3 & 2.8 \\
\hline China & 3 & 2431 & 8539 & 1.6 & 11.4 & 13.4 & 3 & 2046 & 7612 & 1.7 & 9.8 & 12.2 \\
\hline RSA & 2 & 96 & 266 & 1.4 & 0.5 & 0.4 & 2 & 100 & 275 & 1.2 & 0.5 & 0.4 \\
\hline
\end{tabular}

Source: the author's study based on World Bank data. Retrieved from: http://databank.worldbank.org/data/home.aspx [Accessed 05.04.2018]. 
It may be stated that world exports are shifting from the previously largest trade centres to BRICS countries, the share of which in total exports of goods and services is increasing. Such a trend was also observed by Skrzyp (2016); moreover, it may continue in the future.

An analogous situation is observed in the imports of goods and services. In the 1960s, imports from the EU were dominant, accounting for almost $43 \%$ of world imports. In 2015, the share of the EU in global imports was already by almost 10 percentage points lower, while it is forecasted that by 2070 , despite an increase in absolute import value, it may drop to less than $30 \%$ (Table 1). The role of the USA in global imports may decrease from $14.3 \%$ in 1960 to $12.3 \%$ in 2070. The opposite situation may be reported for BRICS countries which, in the years 1960 and 2015, had a 5 and $15 \%$ share in global imports, while in 2070 their participation may amount to $18 \%$. For this reason, it may be concluded that the role of BRICS countries is increasing and these countries are stabilising their position on the international market (Zalewski, 2013).
A key determinant for trade exchange is associated with population size. Together with a rise in the number of inhabitants of a given country, domestic demand is growing, resulting in the need to increase domestic production (using domestic or imported resources) and/or the need for imports. Assuming the occurrence of the effects of scale and advantageous specialisation this growth stimulates exports, contributing to a growing share in world trade. Such a situation is being forecasted for BRICS countries, in which the population size is increasing more dynamically than in the EU or the USA. In 1960, the world population constituted approx. 3 billion people, while in 2015 it was almost 7.4 billion, of which almost $45 \%$ were living in BRICS countries (Table 2). According to this forecast, in 2070, the global population may be approx. 12 billion, with $4 \%$ (460 million) living in the USA, $5 \%$ (590 million) in the EU and 38\% (4.6 billion) - in BRICS countries (Table 2). Russia is the only country, which may experience a decrease in population size in 2070 in relation to the figure in 2015. The forecast also shows that, in 2070, India and not China (as until recently) may be the most popu-

Table 2. Selected macroeconomic conditions for trade of the EU, the USA and BRICS countries in the years 1960, 2015 and 2070

\begin{tabular}{|c|c|c|c|c|c|c|c|c|c|c|c|c|c|c|c|}
\hline \multirow[t]{2}{*}{ Item } & \multicolumn{3}{|c|}{$\begin{array}{l}\text { Population size } \\
\text { (million) }\end{array}$} & \multicolumn{3}{|c|}{$\begin{array}{c}\text { Share in global } \\
\text { population } \\
(\%)\end{array}$} & \multicolumn{3}{|c|}{$\begin{array}{c}\text { GDP } \\
\text { (USD trillion) }\end{array}$} & \multicolumn{3}{|c|}{$\begin{array}{c}\text { Share in global GDP } \\
(\%)\end{array}$} & \multicolumn{3}{|c|}{$\begin{array}{c}\text { GDP per capita (USD } \\
\text { thousand) }\end{array}$} \\
\hline & 1960 & 2015 & 2070 & 1960 & 2015 & 2070 & 1960 & 2015 & 2070 & 1960 & 2015 & 2070 & 1960 & 2015 & 2070 \\
\hline World & 3034 & 7355 & 11902 & 100 & 100 & 100 & 1.4 & 74.5 & 212.3 & 100 & 100 & 100 & 0.5 & 10.1 & 17.8 \\
\hline EU & 409 & 510 & 588 & 13 & 7 & 5 & 0.4 & 16.3 & 38.1 & 26 & 22 & 18 & 0.9 & 32.0 & 64.8 \\
\hline USA & 181 & 321 & 463 & 6 & 4 & 4 & 0.5 & 18.0 & 46.9 & 40 & 24 & 22 & 3.0 & 56.2 & 101.2 \\
\hline $\begin{array}{l}\text { BRICS, } \\
\text { including: }\end{array}$ & 1326 & 3085 & 4570 & 44 & 42 & 38 & 0.1 & 16.7 & 62.4 & 9 & 22 & 29 & 0.1 & 5.4 & 13.7 \\
\hline Brazil & 72 & 206 & 318 & 2 & 3 & 3 & 0.0 & 1.8 & 5.6 & 1 & 2 & 3 & 0.2 & 8.8 & 17.6 \\
\hline Russia & 120 & 144 & 135 & 4 & 2 & 1 & . & 1.4 & 4.7 & . & 2 & 2 & . & 9.5 & 35.0 \\
\hline India & 449 & 1309 & 2244 & 15 & 18 & 19 & 0.0 & 2.1 & 8.0 & 3 & 3 & 4 & 0.1 & 1.6 & 3.6 \\
\hline China & 667 & 1371 & 1779 & 22 & 19 & 15 & 0.1 & 11.1 & 43.3 & 4 & 15 & 20 & 0.1 & 8.1 & 24.3 \\
\hline RSA & 17 & 55 & 93 & 1 & 1 & 1 & 0.0 & 0.3 & 0.8 & 1 & 0 & 0 & 0.4 & 5.8 & 8.6 \\
\hline
\end{tabular}

Source: the author's study based on World Bank data. Retrieved from: http://databank.worldbank.org/data/home.aspx [Accessed 05.04.2018]. 
lous country worldwide. Despite an increase in population size, in most investigated countries, their share in world population may be decreasing. Exceptions in this respect may be India and RSA which are experiencing very high birth rates. In 1960, the inhabitants of India accounted for approx. 15\%, in $2015-18 \%$, while in 2070 they may account for $19 \%$ of the global population.

A major economic factor stimulating demand, also including foreign goods, is connected with the level of GDP and disposable income of a population. In 1960, the highest gross domestic product was generated in the USA. It amounted to USD 0.5 trillion, which accounted to almost $40 \%$ of world GDP. At that time, the EU generated 26\%, while for BRICS countries it was $9 \%$ of global GDP (Table 2). In 2015, the GDP value for the three investigated economies was uniform and amounted to USD 16-18 trillion, which was equivalent to $22-24 \%$ of world production. The simulation for the year 2070 indicates the highest GDP for BRICS countries (USD 62.5 trillion), which would generate $30 \%$ of global GDP, a $22 \%$ share of the USA (USD 47 trillion) and an 18\% share of the EU (USD 38 trillion). This analysis shows that the role of the USA and the EU measured by GDP is decreasing to the advantage of BRICS countries. Although GDP values for the EU and the USA were increasing in the analysed years, their respective shares in the generation of global gross product was decreasing. To a considerable extent this was caused by China which, starting from the 1980 s, has been experiencing a very high, frequently double digit growth rate in GDP, as reported by e.g. by Gwiazda (2013) and Sulmicki (2015). It is likely that, in 2070, the GDP for China may exceed the EU GDP. Interesting conclusions are provided by the analysis of GDP per capita. Throughout the entire investigated period, the highest GDP per capita was recorded in the USA, a country with the smallest population among investigated entities. In 1960, it was USD 3 thousand, in 2015 USD 56 thousand, while in 2070 it may exceed USD 100 thousand (Table 2). All BRICS countries, in terms of their GDP per capita, are located around the world mean (USD 450 in 1960, 10 thousand in 2015 and according to the forecast - 18 thousand in 2070). The dynamic development of BRICS countries has resulted in a significant increase in the demand for raw materials in these countries. Since production may not satisfy demand, these countries are forced to continuously increase imports, which is reflected in the growing shares of this group of countries in world imports (Skrzyp, 2016).

Inflation is an important factor determining the cost leadership of individual countries on regional and world markets. Its increase, through changes in price relationships, causes a reduction of exports and an increase in imports from/to a given country, and thus leads to a trade deficit, which in the short term

Table 3. Inflation rates in the EU, the USA and BRICS countries in the years 2000-2016 (\%)

\begin{tabular}{|l|c|c|c|c|c|c|c|c|c|}
\hline Item & 2000 & 2002 & 2004 & 2006 & 2008 & 2010 & 2012 & 2014 & 2016 \\
\hline World & 3.6 & 3.1 & 3.7 & 4.5 & 8.9 & 3.5 & 3.8 & 2.5 & 1.7 \\
\hline EU & 3.2 & 2.3 & 2.3 & 2.6 & 4.2 & 1.7 & 2.7 & 0.2 & 0.2 \\
\hline USA & 3.4 & 1.6 & 2.7 & 3.2 & 3.8 & 1.6 & 2.1 & 1.6 & 1.3 \\
\hline Brazil & 7.0 & 8.5 & 6.6 & 4.2 & 5.7 & 5.0 & 5.4 & 6.3 & 8.7 \\
\hline Russia & 20.8 & 15.8 & 10.9 & 9.7 & 14.1 & 6.9 & 5.1 & 7.8 & 7.0 \\
\hline India & 4.0 & 4.4 & 3.8 & 6.1 & 8.4 & 12.0 & 9.3 & 6.6 & 4.9 \\
\hline China & 0.3 & -0.8 & 3.9 & 1.5 & 5.9 & 3.3 & 2.6 & 2.0 & 2.0 \\
\hline RSA & 5.3 & 9.2 & 1.4 & 4.6 & 11.5 & 4.3 & 5.7 & 6.1 & 6.3 \\
\hline
\end{tabular}

${ }^{*}$ Time range of this set of data is dependent on the availability of reliable and internationally comparable data.

Source: author's study based on World Bank data http://databank.worldbank.org/data/home.aspx [Accessed 05.04.2018]. 
can be considered a manifestation of lack of competitiveness of the economy on international markets. In the analysed years, creeping inflation from 3 to $5 \%$ was recorded. An exceptional year in this respect was 2008 , the year of the economic crisis, when the inflation rate reached almost 9\% (Table 3). Economies of the EU and USA are closely interconnected, thus the level of inflation in these economies was comparable. In the years 2000-2016, inflation in China fluctuated from -0.8 to $5.9 \%$, reaching deflation twice, while becoming an increasingly solid trade partner for other major economic centres. The economies of Brazil, India, RSA and Russia were less stable on an international scale and inflation fluctuations in those countries were greater, as they experienced walking inflation and in some years - galloping inflation. It was particularly evident in Russia (over $20 \%$ inflation in 2000). Russia is a specific economy, since its economic potential is mainly based on oil, the price fluctuations of which may stimulate an increase in inflation. Considering the above-mentioned facts, it can be concluded that, in the long-term perspective, the rate of economic growth is a decreasing function of the inflation rate, and its relatively high level recorded in BRICS countries may cause a slower pace of their current dynamic development.

\section{CONCLUSIONS}

Changes in the balance of powers on the international market have been observed since the 1990s. The EU, the USA and BRICS countries are the three main trade centres on a global scale and jointly have over a $60 \%$ share in global exports and imports. However, these analyses showed that the current largest global trade centres, i.e. the EU and the USA, are losing their share in global GDP. Their share in world exports and imports is also decreasing to the advantage of the dynamically developing BRICS countries. The growing importance of Brazil, Russia, India, China and RSA, on an international scale, was determined, among other things, by dynamic population growth and an increase in GDP of these countries, while the strengthening of the economic position of China was also connected with the relatively low inflation rate among the countries of this group. The comparative advantage of BRICS countries on the international market were largely influenced by price and cost advantages, resulting mainly from lower labour costs than in the EU and USA. The observed, increasingly solid change in the balance of economic forces seems irreversible. The simulation up to 2070 has shown that the trends reported in previous years may continue and the position of the EU and the USA in world trade will weaken in relation to the BRICS block.

\section{Acknowledgements}

The paper is funded by the National Science Centre within the OPUS research project 2015/17/B/ /HS4/00262, entitled 'Polish agri-food sector under the implementation of the Transatlantic Trade and Investment Partnership agreement (TTIP)'.

\section{REFERENCES}

1. Bieńkowski, W. (2008). Konkurencyjność gospodarki kraju. Próba rewizji determinant i miar. Przyczyny zmian znaczenia czynników konkurencyjności [Competitiveness of the national economy. A review of determinants and measures. Causes for changes in the importance of competitiveness factors]. In: Bieńkowski, W. et al. (eds.) Czynniki i miary międzynarodowej konkurencyjności gospodarek w kontekście globalizacji - wstępne wyniki badań [Factors and measures of international competitiveness in view of globalisation - preliminary research results]. Prace i Materiały, 284, Instytut Gospodarki Światowej, Warszawa.

2. Błaszczuk, D. (2006). Wstęp do prognozowania i symulacji [Introduction to forecasting and simulation]. Wydawnictwo Naukowe PWN, Warszawa.

3. Bożyk, P. (2008). Międzynarodowe stosunki ekonomiczne [International economic relations]. PWE, Warszawa.

4. BRICS Report (2012). A Study of Brazil, Russia, India, China, and South Africa with special focus on synergies and complementarities. Oxford University Press, New Delhi.

5. Budnikowski, A. (2003). Międzynarodowe stosunki gospodarcze [International economic relations]. PWE, Warszawa.

6. Czarny, E., Folfas, P. (2015). UE i USA w gospodarce światowej [The EU and the USA in world economy]. Presentation. Retrieved from: http://slideplayer.pl/ slide/57082 [Accessed 15.04.2018]. 
7. Cieślak, M. (ed.) (2005). Prognozowanie gospodarcze: metody i zastosowanie [Economic forecasts: methods and applications]. Wydawnictwo Naukowe PWN, Warszawa.

8. Fagerberg, J. (1987). A technology gap approach to why growth rates differ. Research Policy, 16 (2-4), pp. 87-99.

9. Fagerberg, J. (1996). Technology and Competitiveness. Oxford Review of Economic Policy, 12 (3), pp. 39-51.

10. Gosh, J. (2013). The Global Chessboard and the Role of the BRICS: Brazil, Russia, India, China, South Africa. Third World Resurgence, 274.

11. Gwiazda, A. (2013). Globalna ekspansja gospodarcza Chin [Global economic expansion of China]. Wydawnictwo Uniwersytetu Kazimierza Wielkiego, Bydgoszcz.

12. Gururaj, B. Satishkumar, M., Aravinda Kumar, M.K. (2016). Analysis of factors affecting the performance of exports in India. International Journal of Agriculture, Environment and Bioresearch, 9 (4), pp. 613-616.

13. Misala, J. (2005). Wymiana międzynarodowa i gospodarka światowa [International exchange and world economy]. In: The theory and mechanisms of its operation [Teoria i mechanizmy funkcjonowania]. Oficyna Wydawnicza SGH, Warszawa.

14. Nassif, A., Feijo, C., Araújo, E. (2016). The BRICS's Economic Growth Performance before and after the International Financial Crisis. International Journal of Political Economy, 45 (4), pp. 294-314.

15. O’Neill, J. (2001). Building Better Global Economic BRICs. Global Economics Paper, 66.

16. Pawlak, K. (2017). Znaczenie wymiany bilateralnej w handlu zagranicznym produktami rolno-spożywczymi UE i USA [The role of bilateral cooperation in foreign agri-food trade between the EU and the USA] Zeszyty Naukowe SGGW w Warszawie. Problemy Rolnictwa Światowego, 17 (32), 2, pp. 199-210.
17. Pawlas, I. (2015). Uczestnictwo państw BRICS w międzynarodowych obrotach towarowych [Participation of the BRICS countries in international commodity turnover]. In: Sporek, T., Czech, K. (eds.) The BRICS countries and their role in present-day world economy. Wydawnictwo Uniwersytetu Ekonomicznego w Katowicach, Katowice, pp. 61-78.

18. Pelkman, J. (2001). European Integration: Methods and Economic Analysis. Financial Times. Prentice Hall, Essex.

19. Porter, M. (1990). The Competitive Advantage of Nations. The Free Press, New York.

20. Rymarczyk, J. (2006). International economic relations. PWE, Warszawa.

21. Schumpeter, J.A. (1936). The Theory of Economic Development: An Inquiry into Profits, Capital, Credit, Interest and the Business Cycle. Harvard Economic Studies, 46. Harvard University Press, Cambridge.

22. Siddiqui, K. (2016), "Will the Growth of the BRICs Cause a Shift in the Global Balance of Economic Power in the 21st Century?', International Journal of Political Economy, No, 45(4), pp. 315-338.

23. Skrzyp, J. (2016). Stany Zjednoczone i Chiny w ujęciu geopolitycznym [The geopolitical outlook on the United States and China]. In: Jaczyński, S., Kunikowski, J. (eds.) Security culture: needs and conditions. Vol. 1. The Jubilee Book on the 70th birthday of Professor Marian Cieślarczyk, Wydawnictwo Uniwersytetu Przyrodniczo-Humanistycznego, Siedlce, pp. 291-314.

24. Sulmicki, J. (2015). Chiny umacniają dominującą pozycję w gospodarce światowej [China strengthens its dominant position in the world economy]. Akademia Finansów i Biznesu Vistula, Zeszyty Naukowe Uczelni Vistula. Stosunki Międzynarodowe, 41 (3), pp. 33-44.

25. Zalewski, T. (2013). BRICS przeciwwagą USA? [The BRICS as a counterbalance to the USA?]. Puls Biznesu of 30.03.2013. 